\title{
潮升: 边界抗争指南 RISE: A GUIDE TO BOUNDARY RESISTANCE
}

亚历桑德拉 梅 景观设计师、研究者

Alexandra MEI Landscape Designer and Researcher

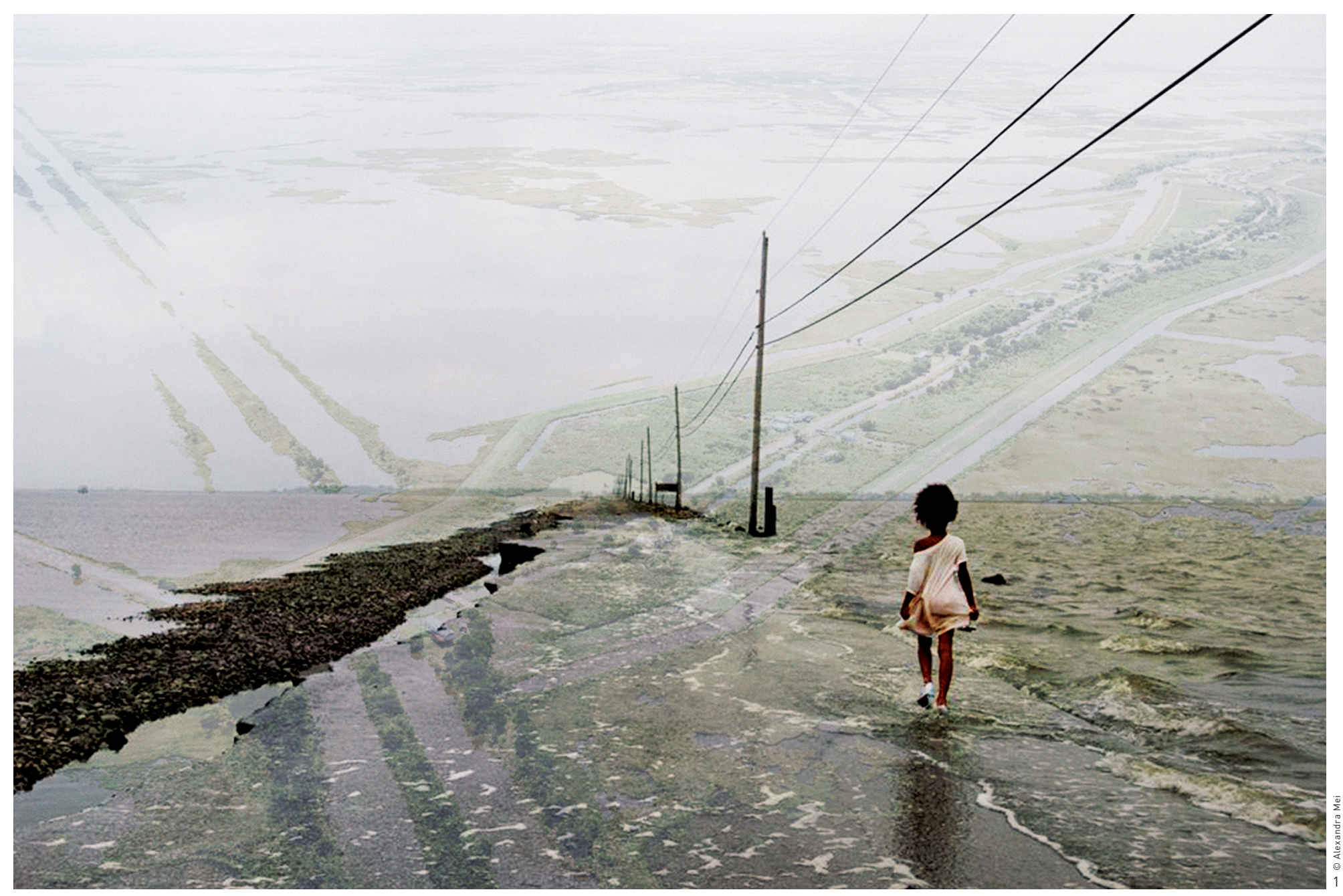


\begin{tabular}{l|l} 
DOI: 10.15302/J-LAF-20170412 & $\begin{array}{l}\text { 收稿时间 RECEIVED DATE / 2017-07-06 } \\
\text { 中图分类号 / TU986 } \\
\text { 文献标识码 / B }\end{array}$
\end{tabular}

商要

指南特有的形式展现出景观设计作为一种具有包容性 分享性以及社会参与性实践的潜能。在这一项目中，指南成 为美国原住民沿海社区挑战由美国陆军工程兵团为岛屿划定 的边界线的媒介。由于海平面上升, 聚居于美国路易斯安那 州让-查尔斯岛上的比洛克西-奇蒂马查-乔克托部落, 被迫 离开他们长期栖居的岛屿, 到北方更远的内陆寻找新的安身 之所。考虑到未来 50 年间平均高水位标记值将随海平面上 升而逐渐升高, 岛屿可能会渐渐转变为国有资产, 而岛民则 会失去对其的所有权。为了应对这一问题, 项目以指南的形 式, 建议岛屿原住民采取行动抵抗用于划定岛屿边界的现有 高水位标记方式，通过遮蔽与模糊岛屿边界来维护部落对其 土地的所有权, 使部落居民迁离该岛后依旧可以返回这片曾 经的家园。通过仔细歁酷表现形式、灵活把控设计过程, 该 项目探讨了社区、抗争以及 “为他者设计” 等议题。在该项 目中，景观设计使我们得以对土地边界线的划定过程展开㘩 判性审视，指南的应用则有助于将岛民及其智慧纳入设计过 程中。

边界; 社区; 参与性；施为者; 身份认同

\section{ABSTRACT}

The format of the guidebook carries potential for landscape architecture as a practice of inclusion, participation and socia engagement. Here, the guidebook is a medium for a native American coastal community to challenge the boundary lines placed onto its island by the Army Corps of Engineers. The Biloxi Chitima Bloxichis is isco farther north because of sea level rise, will eventually lose their island to state property as this mark rises with the sea in the next fifty years. In response, the project uses the guidebook to suggest acts of community resistance against this water mark, obscuring and blurring the boundary so that the tribe will maintain ownership of their land and have a reason to return after they leave. Through conscious choice of representation style and sensitivity to the process of design. the project provoked questions of community, resistance, and "design for the other." Here, the role of landscape architectu "design for the other." is critical of the bon da to place and agency.

KEY WORDS

Boundary; Community; Participation; Agency; Identity

译张健陆小璇

TRANSLATED BY Angus ZHANG Xiaoxuan LU

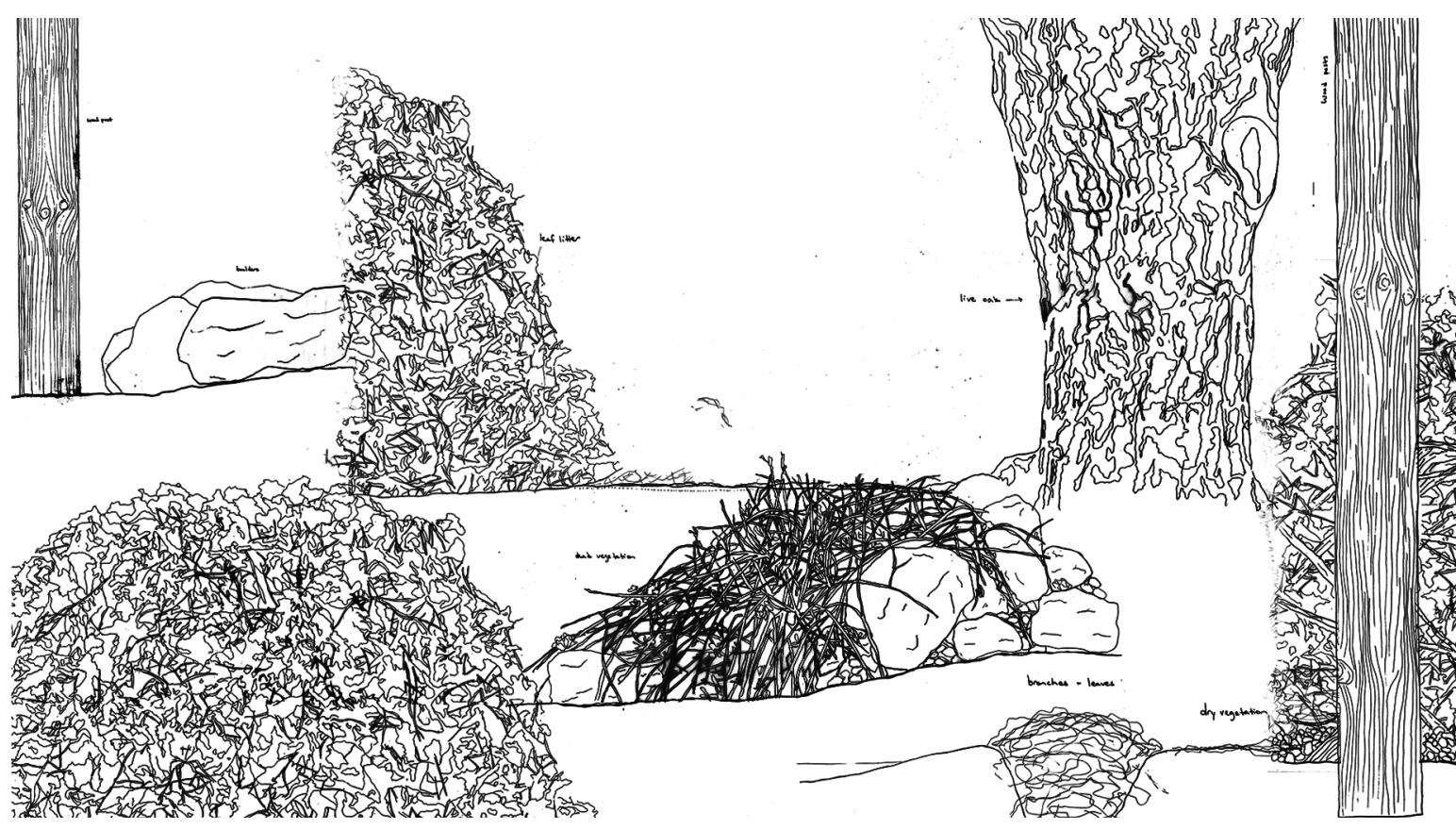

概述：让一查尔斯岛

让一查尔斯岛坐落于美国路易斯安那州最 南端, 海拔仅数米, 自19世纪初以来一直是 比洛克西-奇蒂马查-乔克托部落所栖居的地 方。1830年, 美国政府颁布《印第安人迁移 法》, 部落先民在此寻得了安身之所。在那 时, 让一查尔斯岛上多为森林湿地, 部落居民 孕育出了丰富的渔业、本土手工业和园艺文 化。直到近半个世纪以前, 让一查尔斯岛才出 现既几乎完全被水环绕，但又未与路易斯安 那州大陆完全分离的情况。如今, 岛民们仍 记得当初岛屿还是一处高地时的情形：岛上 遍布水松和蒲葵, 人们在后院中捡拾柿子, 而 小鸡、奶牛和兔子则四处悠闲地漫步。

20 世纪 50 年代之后, 由于海平面上 升、风暴肆虐、缺少泥沙沉积和地面沉降等 原因，岛屿上 $98 \%$ 的土地已不复存在。不
断开拓的海上石油工业则是激化这些问题的 元凶一人们疏浚出长达约14 $500 \mathrm{~km}$ 的运 河, 并在南部海岸区域挖掘了5万口油井, 这 使得原本已十分脆弱的土地遭受了进一步的 切割和破坏。据政府预测，若不采取任何对 策, 到2050年, 人们将无法再踏足让一查尔 斯岛; 而到21世纪末, 岛屿将完全淹没于水 下。为应对这一危机，美国住房和城市发展 部为该岛提供了4 800万美元的资助。然而, 这笔经费并非为了帮助岛民拯救岛屿, 而是 用以协助他们在北方更远的内陆寻找新的安 身之所。自此, 让一查尔斯岛社区的居民成为 了美国第一批 “气候难民”。

尽管被贴上了这样一个并不令人愉快的 标签, 但这批美洲原住民的迁移安置行动, 却实际突显了他们对岛屿的控制权利——即 使撤离, 他们仍将保留岛屿的所有权, 也依 旧可以返回这片曾经的家园，在岛屿周围的 


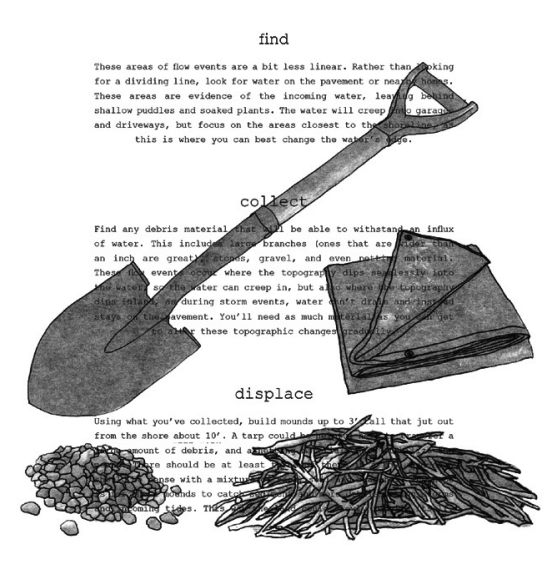

[move]

MULTRE OSERRVED RLOW EVENTS
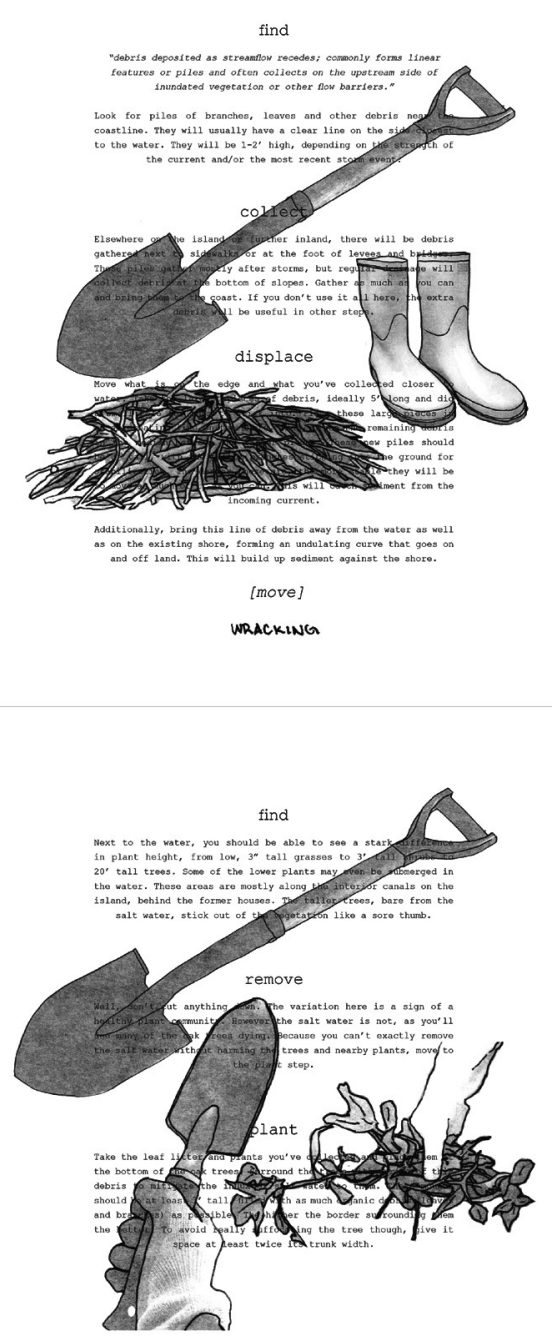

[grow]

CHANGE IN PLANT COMMUNITY

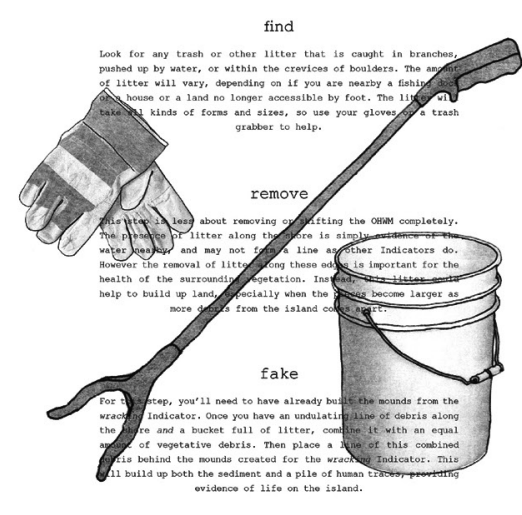

[scrub]

Presence \& LITER. desris

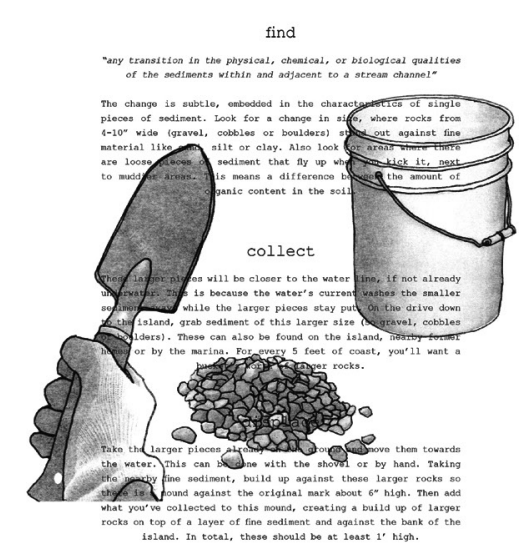

[move]
CHANGES IN CHARACTER OF SOIL

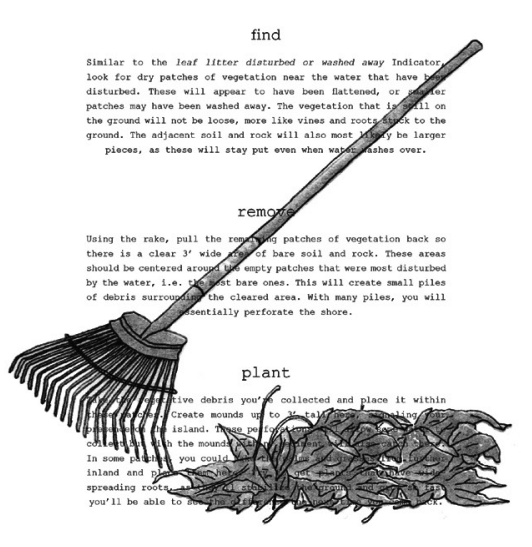

[grow]

VEG BTATION MATED DONN, BENT GR ABSENT

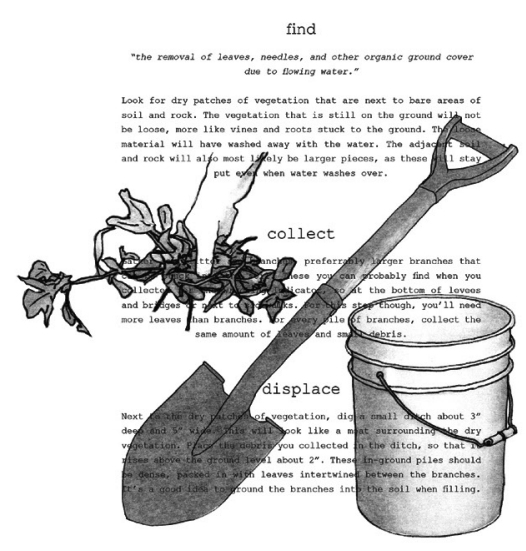

[move]

LEAF LITTER DISTRRBEO OR WASHEO AWAY

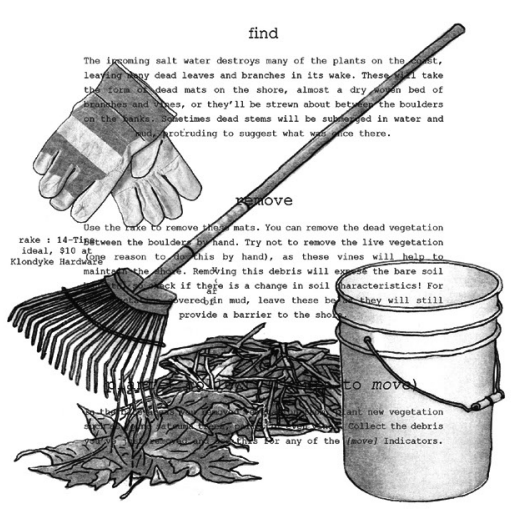

[grow]

DESTRUCTION OF TERRETTALL VEGETATI ON
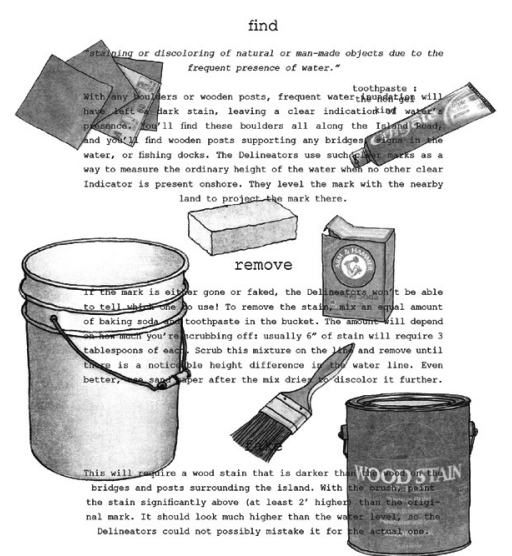

[scrub] 
略和试验。通过关注类似于OHWM这类便于 政府机构展开控制而强行划定的水域及陆域 边界，该项目提出了具有持续性、本土性以 及集体性的景观干预策略，以期在对已有边 界发出挑战的同时, 维护比洛克西-奇蒂马 查-乔克托部落的身份认同感。

\section{形式：边界抗争指南}

该指南列举了可与目前应用于让一查尔 斯岛的OHWM的相关特征进行抗争的具体方 式。有了这份指南, 岛上居民将可以抵抗逐 渐向岛内侵占的海水边界, 以维护岛屿所有 权。通过详细阐述水位标记的性质和掌控这 条界线的制定机构及机制，该指南试图使这 条边界的制定过程透明化，以进一步向其发 起质疑。指南的最终目的是促进一种以原住 岛民为主体，以周或月为操作周期，具有文 化性及公众参与性的长期护岛行为。

除这些较小规模的干预措施外，项目 亦考虑到在上述具有策略性的护岛行为得以 实施的基础上，如何从更高远的视角统筹规 划岛屿形态。通过综合考量已知的最佳捕鱼 点、岛上住宅现状，以及公墓和码头等的位 置, 岛屿未来的形状及地势应为实现社区的 预期目标而服务。在此要指出的是, 对这些 岛屿形态进行构想的目的，并非是使整个岛 屿免受海水上升的侵扰。相反, 这些构想希 冀通过岛民对其居住已久的土地的了解和理 解，稳固其对岛屿的所有权以及对周边水域 的使用权。

该指南将景观设计实践作为一种规划过
程, 而非解决方案。其特有的形式一方面提 供了改变沿海地带边界的方法, 另一方面则 鼓励当地部落通过自己的知识和期许来塑造 土地。景观设计的专业知识并非旨在制定出 最终的方案, 而是提供指导。此外, 通过鼓 励采取行动而非提供解决方案, 该项目将目 光集中于积极塑造着路易斯安那州景观的当 代美国原住民文化。通过社区的持续行动， 岛屿仍将归属于部落居民。在塑造土地的同 时, 比洛克西-奇蒂马查-乔克托部落的身份 特征也将被重新确立并不断强化。由此, 在 文化与景观之间所形成的相互依存的关系， 凸显了“土地” 在当前关于政治界线的讨论 中的重要地位。社会形态于景观实践中萌 发, 反之, 土地则由其所承载的记忆和身份 特征所塑造。

\section{呈现：述行性成果汇报}

该项目进一步对样本呈现的汇报方式展 开探索, 以期传达边界抗争指南所具有的个 人化、可触化的特征。毕业设计的最终汇报 成果包括美国陆军工程兵团用于划定水域边 界的文件、得以展现OHWM中各项特征的生 物材料模型、指南中列出的每项行动的剖面 图和平面图、指南副本, 以及收集而来的让一 查尔斯岛与岛上部落的照片。上述各项材料 由手绘图、照片拼贴, 以及经过仔细推敲的 如纸张或土壤等输出材料综合呈现。

除进行以上工作外，最终汇报以一本70 页的图册 $(90 \mathrm{~cm} \times 60 \mathrm{~cm})$ 进行呈现。每 一页都以标准建筑施工图的形式展示了岛屿

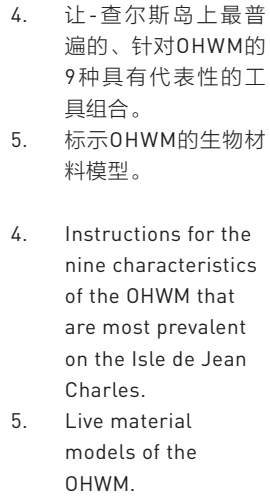

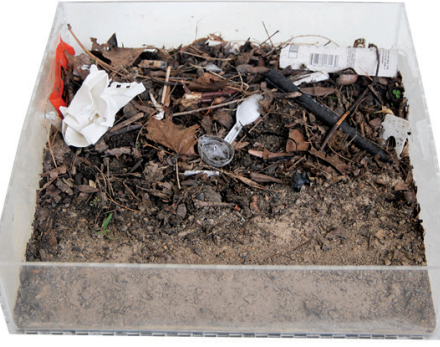

presence of litter and debris 垃圾和碎屏

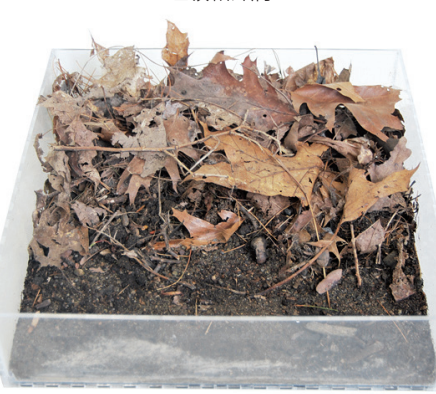

leaf litter disturbed or washed away 被㨡乱或冲走的落叶

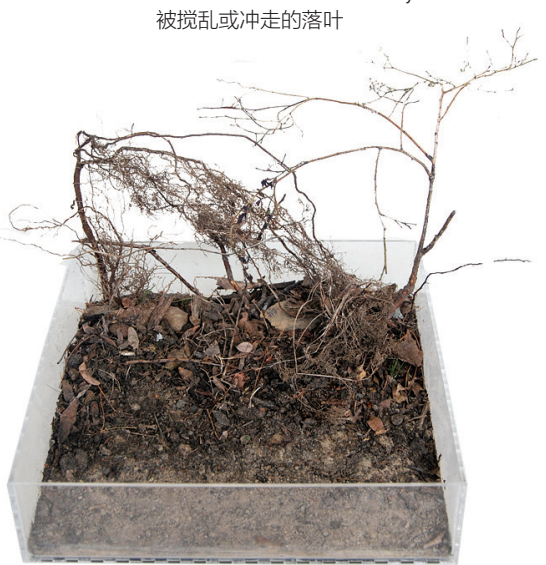

destruction of terrestrial vegetatio 被破坏的陆地植被

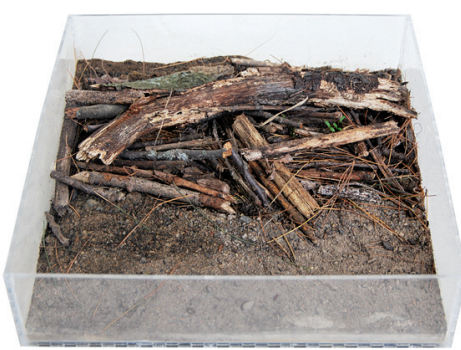

wracking

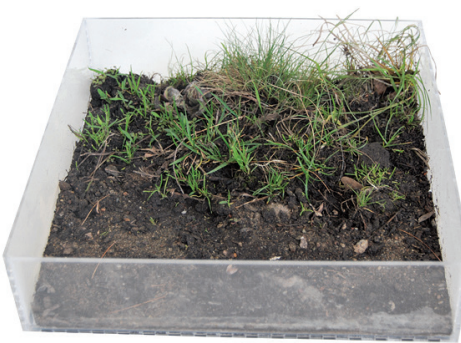

multiple flow events 多种渗流讨程 


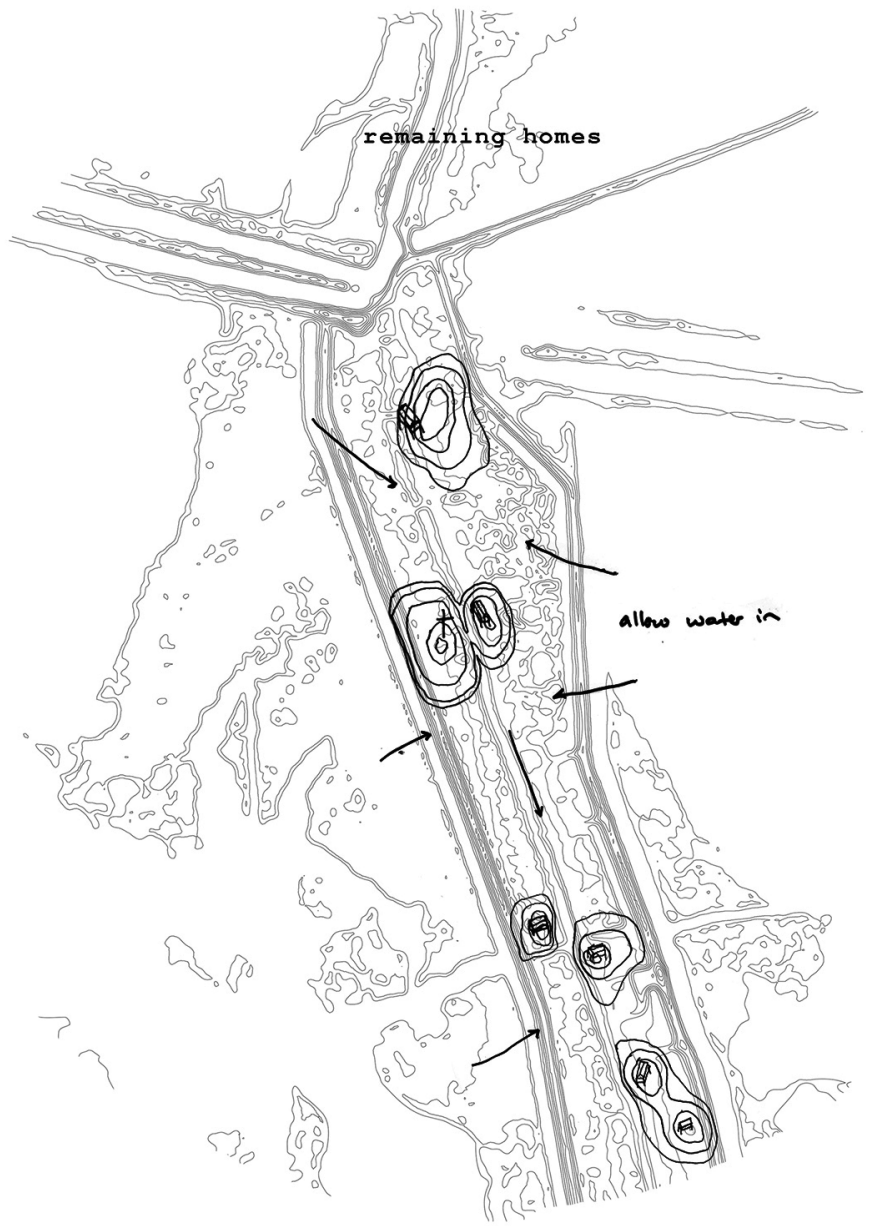

的周边环境与空间信息。此外, 图册的每一 页上都附有一张半透明夹页, 每张夹页都通 过勾画出与其下图片的位置及尺度相符的岛 屿的边界位置, 强调州政府在土地上强制绘 制边界的行为。综上所述, 毕业设计的最终 汇报是对如下三方面的平行呈现: 岛屿的直 观物理性质、决定其地图呈现的边界制定机 制, 以及指南中所提议的可与边界相抗争的 社区行动。

对项目呈现风格的有意考量一或是 说对一般呈现方式的有意颠覆一一是一种将 景观现状及最终设计与公共实践相结合的实 验。通过融合手绘图的触感、图册的直观性 以及指南所具有的可识学性, 该项目旨在构 建一种面向沿海社区居民的行动及决策机 制。这种联系是一种不同于州政府与岛民之
间现有关系的、存在于我们俗称的“设计 师”与 “委托方”之间的新的联系。

\section{反思：关于实践}

该项目萌发于我对让一查尔斯岛数量巨 大的人口迁置现状的关注, 亦是我对自身在 景观设计实践中所扮演角色的个人探究。由 于不存在预算及合法性的限制, 我的毕业设 计有幸对如何使景观设计在那些位于气候变 化前线的沿海社区发挥最大作用的议题展开 探讨。在这一过程中我逐渐发现, 传统意义 上总体规划图的制定，对于上述目标的实现 并非是必要的。在本项目所探讨的议题中,

“设计”是需要作出适时改变的流动的过 程。最为重要的是, “设计”的形成应当基

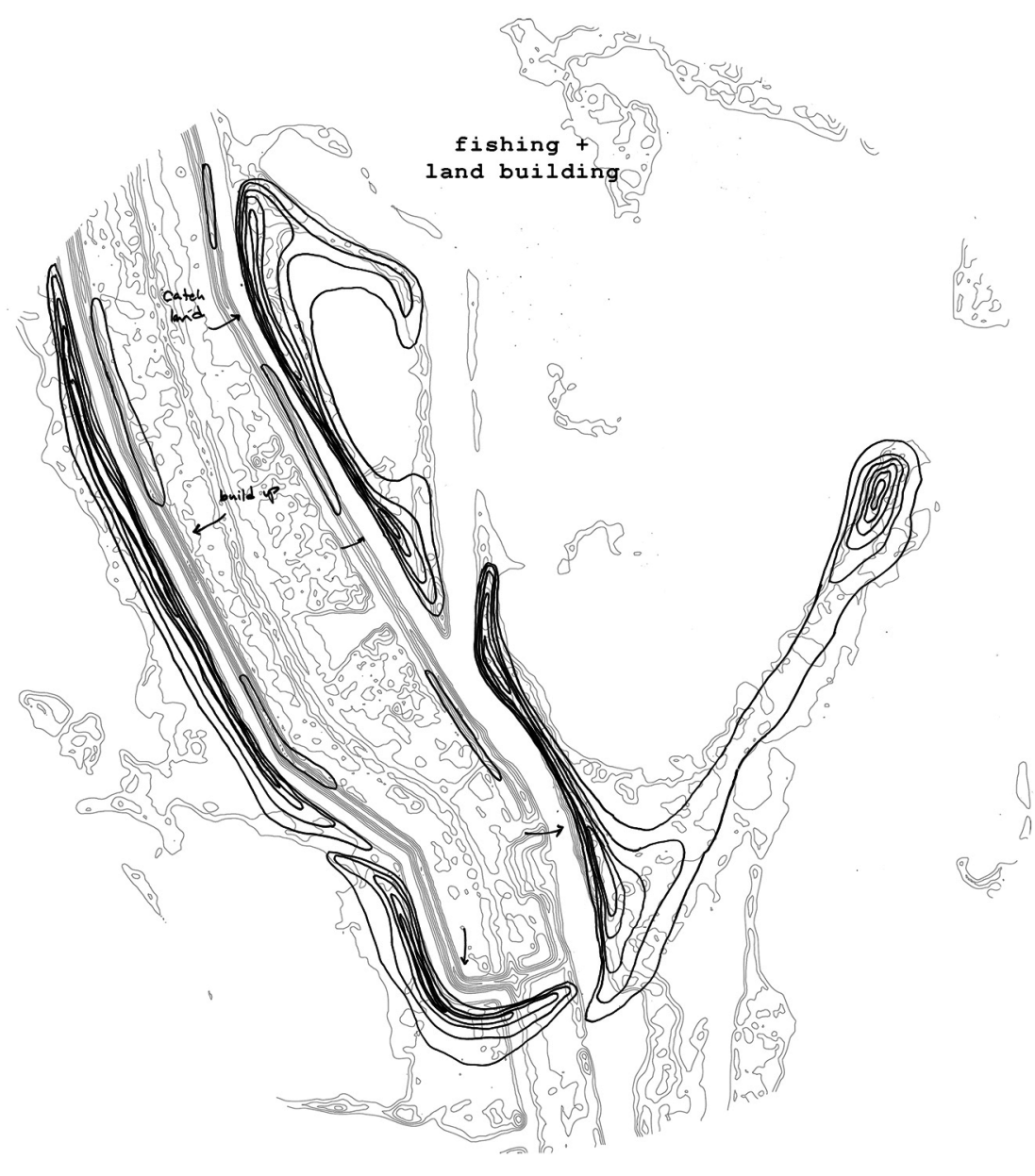

于对现实存在的、具有文化和物理特征的景 观的深入了解。在该项目中, 边界抗争指南 所具有的灵活而可触知的特征, 不但保证了 对土地的塑造行为被交还给那些与其生息最 直接相关的岛上社区的手中, 亦使景观设计 师的地位在岛民塑造土地的长期行为中得以 保存和延续。因此, 基于对景观中所蕴含的 力量和那些对本地社区有着深刻理解和尊重 的政府机构的了解和认知, 景观设计能够发 挥其更大的潜能, 以应对不断出现在我们周 围的物理和社会边界。LAF

注释

该项目为作者在哈佛大学设计研究生院攻读景观设计硕士时的设计 项目, 由罗伯特.皮埃特鲁斯科教授指导。该项目获得了由哈佛大 学设计研究生院景观设计系颁发的毕业设计奖。 


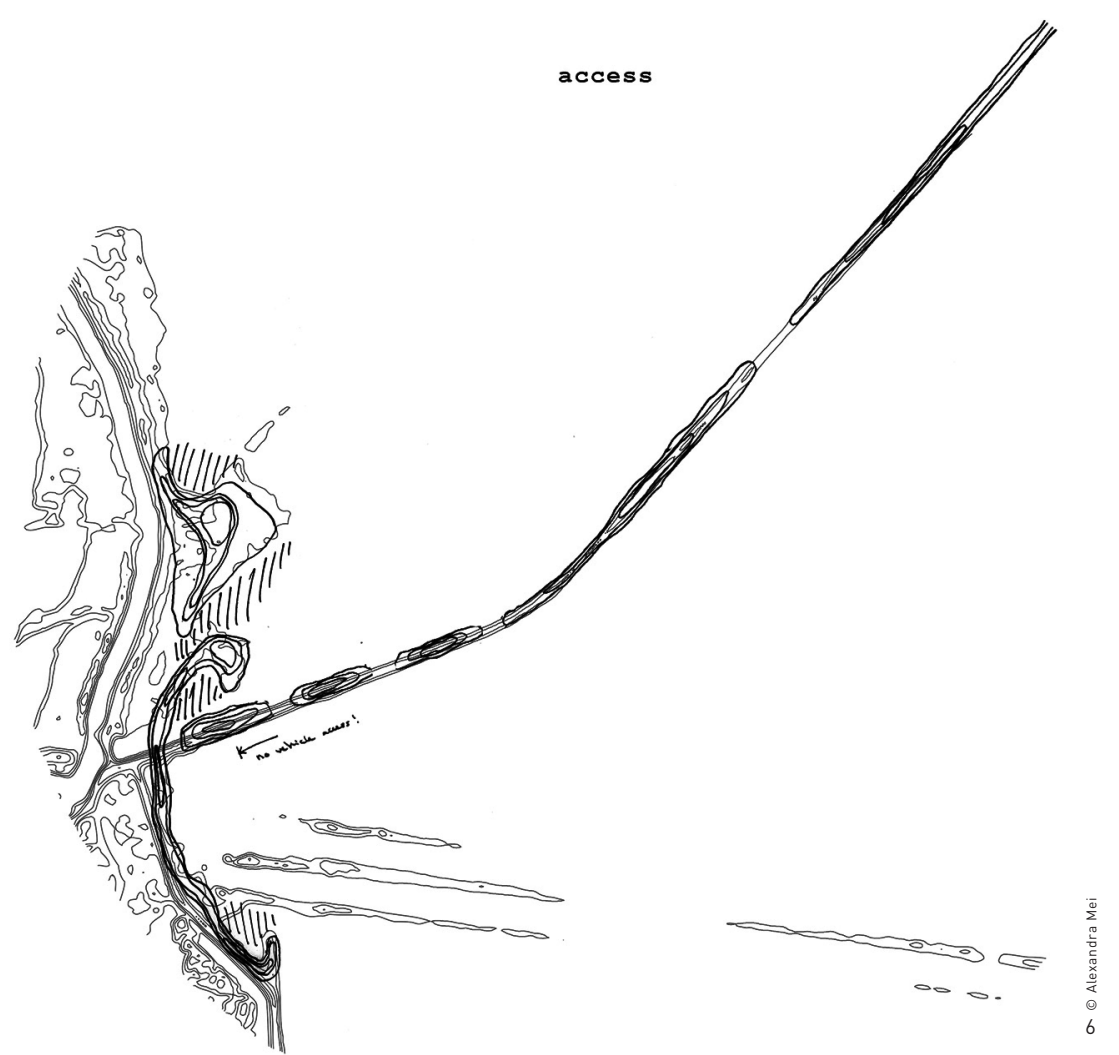

Narrative: The Isle de Jean Charles

At the southern-most edge of Louisiana, with an elevation of just a couple meters, is the Isle de Jean Charles, home to the Biloxi Chitimacha Choctaw tribe since the early 1800 s. Here, early ancestors found refuge after the United States Indian Removal Act of 1830. In these earlier days, the island was a forested wetland, and the tribe cultivated a rich culture of fishing, making and gardening. Only in the last half century has the Isle de Jean Charles been both connected to the mainland state and surrounded entirely by water. Today, the residents remember when the island was high ground, covered with bald cypresses
6. 依据比洛克西-奇蒂马 查-乔克托部落期望的 目标, 构想出的可能的 岛屿形成方式。

6. Possible island formations according to desired goals of the Biloxi chiti Choctaw. and palmettoes, when they would pick persimmons from their backyard gardens, and when chickens, cows and rabbits would roam the island.

Since the 1950s, the island has lost $98 \%$ of its land. This is due to sea level rise, severe storms, lack of sediment deposition and land subsidence. These issues were ignited by the presence of the oil industry on the coast, with 9,000 miles of canals dredged and 50,000 oil wells dug into the southern coast, cutting through and destabilizing the already fragile land. If nothing is done for the island, the state predicts that the Isle de Jean Charles will be inaccessible by 2050 and completely submerged underwater by the end of the century. In response, the 

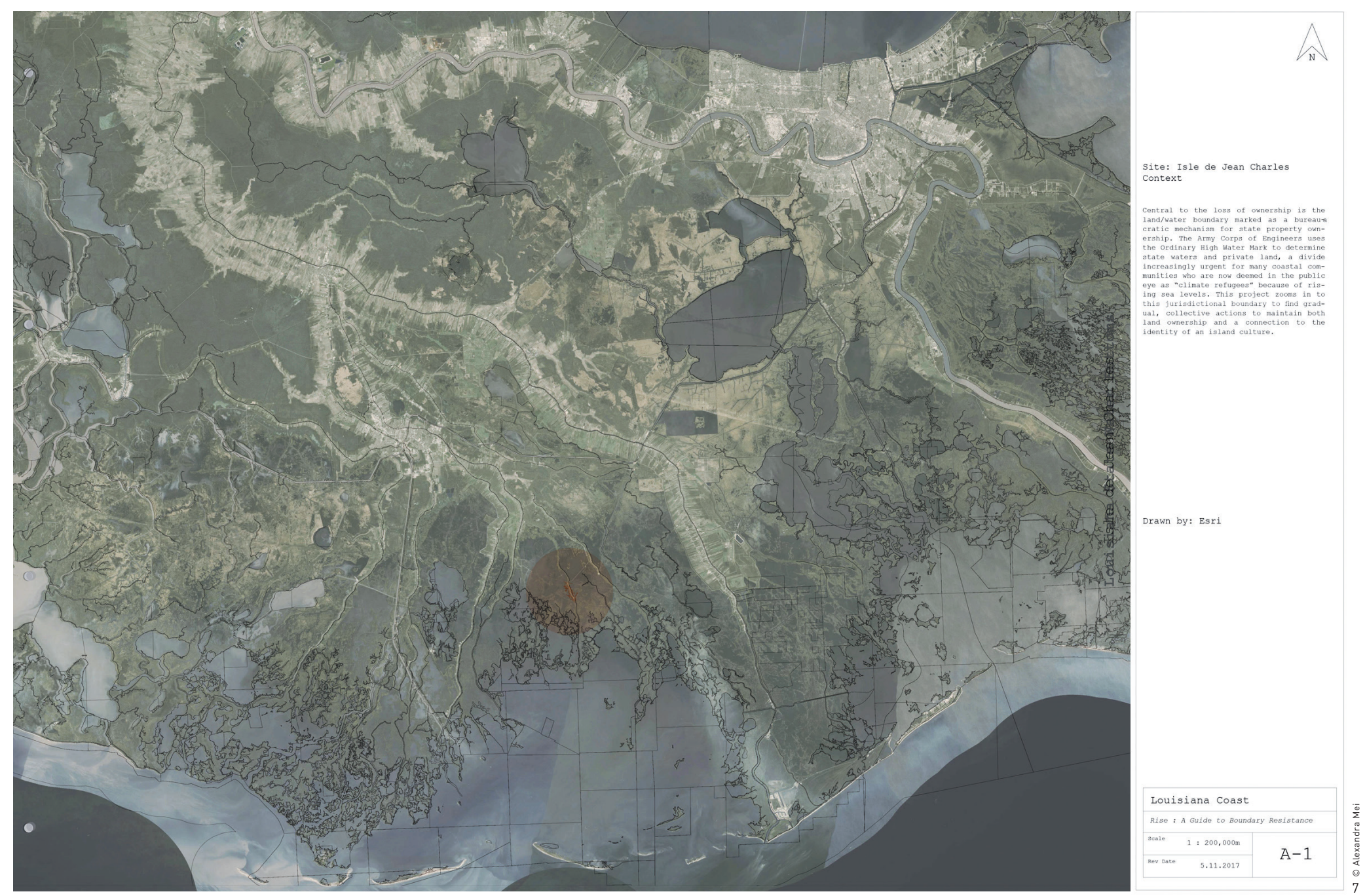

island community received a grant of 48 million USD from the U.S. Department of Housing and Urban Development not to save their island, but to resettle their home farther north to a land-locked parcel of land, labeling this community as the first "climate refugees" in the United States.

Despite this unwanted label, the Native American community's resettlement is actually an act of agency over their island, as they will still maintain ownership of the island even after they leave. This ownership will allow them to continue to visit their home and to access the surrounding waters for the fishing and farming the area is known for. However, once the water completely submerges the island, it will belong to the state. According to federal and Louisiana state law, the state owns "all land that is navigable and below high water in the winter season." This state property is physically delineated on land by the Ordinary High Water Mark (OHWM), a formation of several physical characteristics on the ground that the Army Corps of Engineers has determined to be the divide between land and water. As the water mark rises, the Biloxi Chitimacha Choctaw's property diminishes and eventually disappears. Zooming in to closely analyze the OHWM
7. 让-查尔斯岛 (图中红 色部分) 和划定的路易 斯安那州水域范围。

7. Isle de Jean Charles (in red) and the designated Louisiana state water bottoms. 


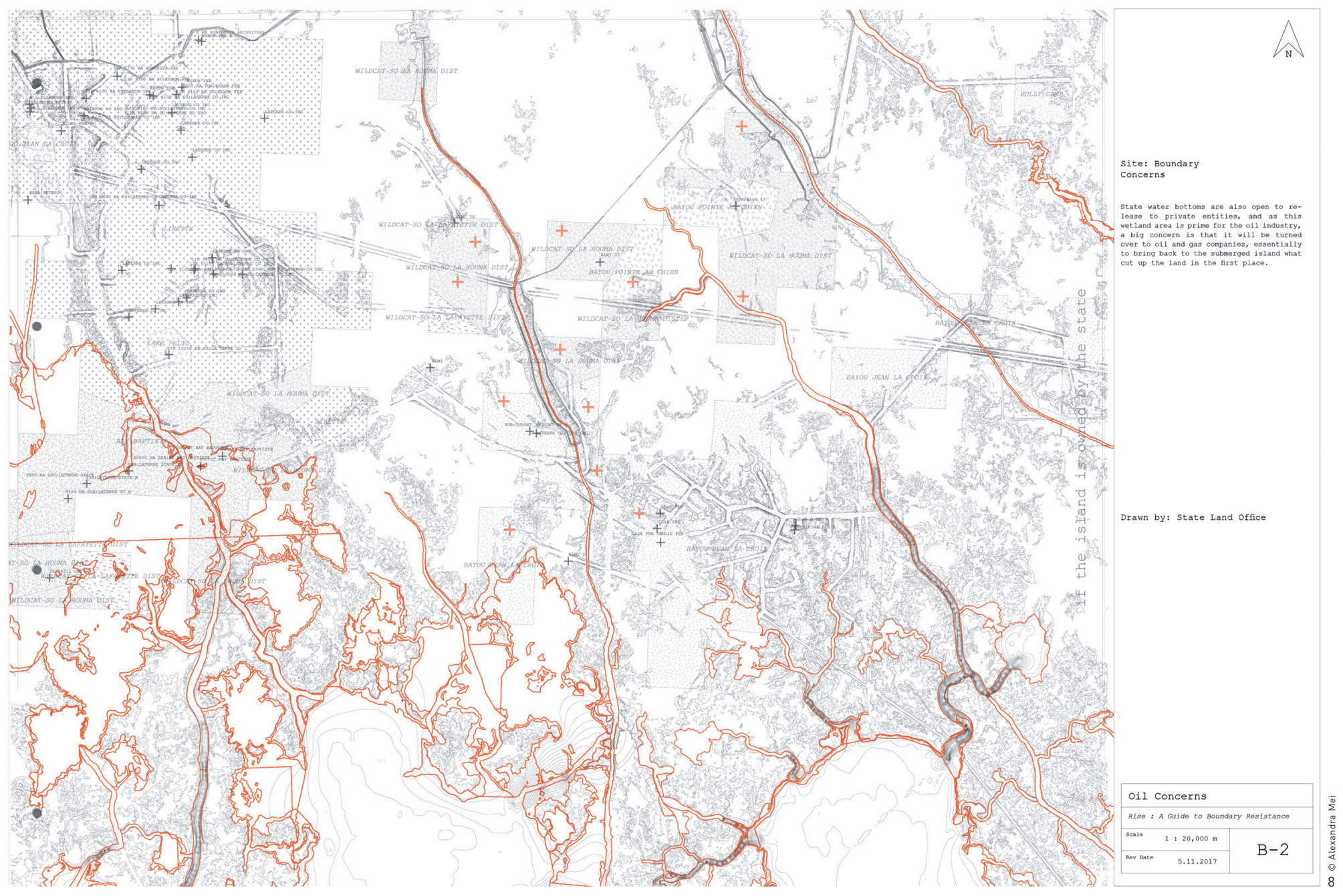

on the Isle de Jean Charles, we see that the boundary line can actually be altered and obscured to effectively challenge the imposed division between water and land, state and native.

This project is interested in methods and experiments that situate landscape architecture as a practice of inclusion, participation and social engagement. By focusing on boundaries like the OHWM that are placed on the land for bureaucratic control, the project proposes continued, local and collective action on the landscape that both challenges these lines and sustains local identity.

\section{Format: The Guide for Boundary Resistance}

The guidebook outlines the specific actions necessary to combat each characteristic of the OHWM on the Isle de Jean Charles. With this, the community can resist the encroaching water boundary to keep their island their own. Explaining the nature of the water mark, who delineates it, and their process of marking, the guide intends to make such boundary-making transparent in order to effectively challenge it. Ultimately, the guidebook imagines a cultural and generational undertaking
8. 如果让-查尔斯岛归州 政府所有, 将被作为原 油产业区的区域。

8. Map of the projected oil industry if the island is owned by the state. 
of weekly and monthly actions that will transform the community's island over time.

In addition to these smaller scale interventions, the project zooms out to find possible island forms if these actions play out strategically on the island. Based on the spots known to have the best fishing, the homes currently on the island, and the location of the island cemetery and marina, these future landforms address possible desired goals of the community. It is critical to note that these forms do not attempt to save the entire island from rising sea levels. Instead, they use community knowledge and understanding of the land the tribe has lived on for so long, in order to maintain ownership and access to their waters.

This guidebook posits a practice of landscape architecture that is a projection, rather than a solution. Its format provides methods for changing these boundaries imposed onto coastal lands while encouraging the local tribe to use their knowledge and goals to shape their own land. The expertise of landscape architecture is used as a guide rather than a definitive answer. Further, by encouraging action over solutions, the project focuses on the present-day Native American culture that is active in shaping Louisiana's landscape. Through the persistent action of the community, the island is still their own. And, as a product, their identity as the Bilox
Chitimacha Choctaw is strengthened and continuously re-established as they shape their land. Here, culture and landscape have a co-dependency that renders the land evermore present in our current conversation of political boundaries. Social formation is derived through landscape practices and conversely, the land is formed by the memory and identities embedded in it.

\section{Representation: A Performative Review}

The project was further explored through analog representation techniques that conveyed the personal, tangible nature of the guidebook proposal. The final presentation included the documents which the Army Corps uses to delineate the water boundary, live material models of each characteristic of the OHWM, sections and plans of each action outlined in the guidebook, copies of the guidebook itself, and collected photos of the Isle de Jean Charles and the tribe. Each of these combined hand drawing, photo collage, and a careful consideration for the output material, be it paper or soil.

In addition to this work, the actual presentation consisted of flipping through a 70 -page, 3 feet $\times 2$ feet drawing set. Each page was formatted like a standard construction document showing the context and spatiality of the island. But as part of the drawing set, translucent sheets were also placed on top of each page and outlined the boundary placed on the island at every scale, emphasizing the state's act of imposing boundaries on the land with each image. All together, the presentation became a performance that paralleled the physicality of this island, the boundary formations defining its existence, and the proposed acts of resistance.

The consciousness, and perhaps subversion here of representation style is an experiment in how landscape, and its resulting design, can be uniquely connected to communal practice. With the tactility of hand drawing, the accessibility of the drawing set, and the adaptable nature of the guidebook itself, the project seeks to form a relationship with coastal communities that posits an alternative to the current state and resident relationship, suggesting a new connection between so-called designer and client.

\section{Reflection: A Question of Practice}

This project is an extension of my interest in the massive displacement of populations we are witnessing today, as well as a personal investigation of my own role in the practice of landscape architecture. Without the confines of a budget or any

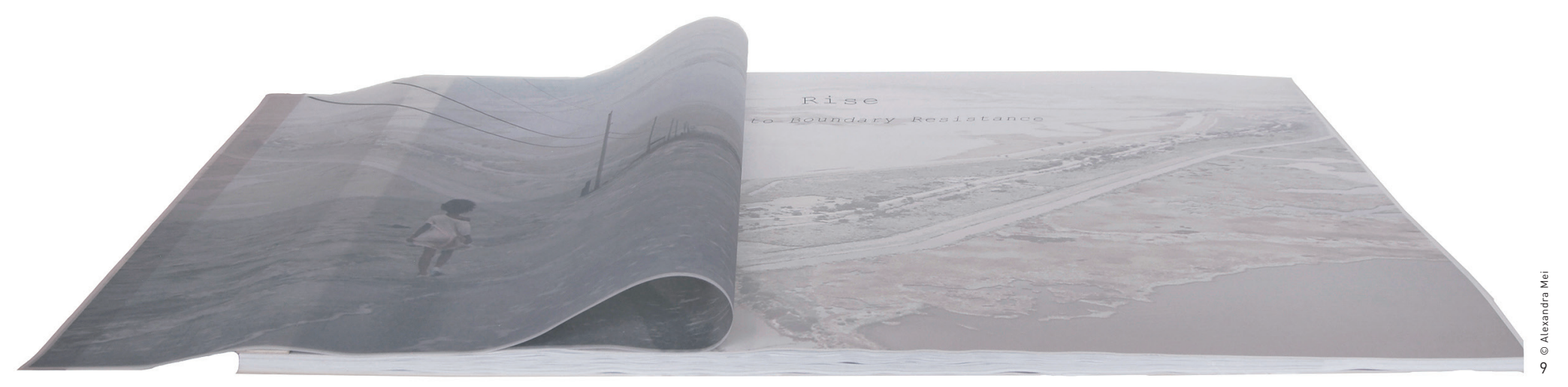


9. 用以展示该项目的图集。

. 收集到的让-查尔斯岛和 比洛克西-奇蒂马查-乔克 托部落的照片。

11. 图集最终成果展示。

9. Drawing set used to present the project.

10. Collected photos of the Isle de Jean Charles and the Biloxi

11. Final presentation of the drawing set.
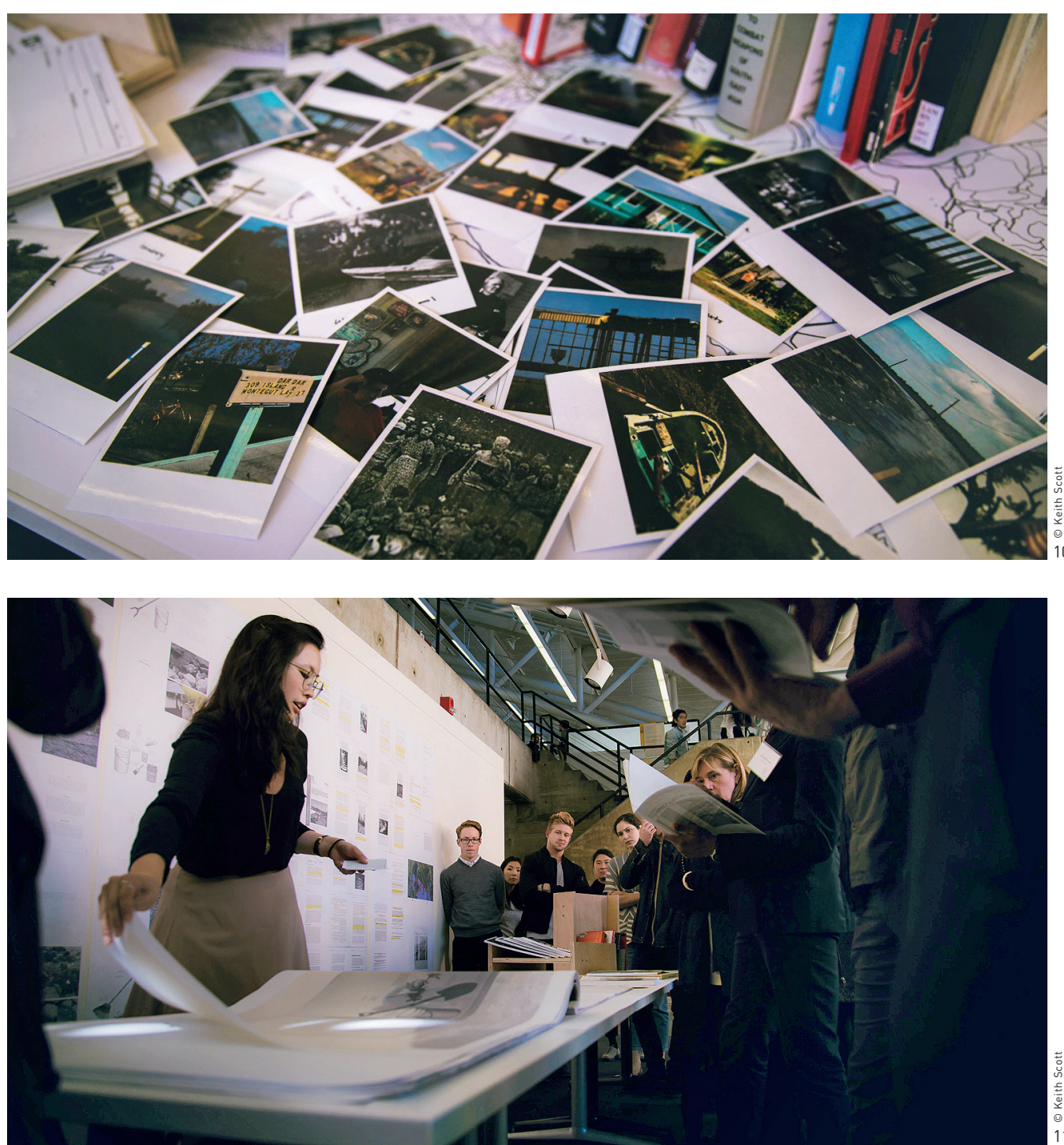

legalities, I had the privilege to explore how landscape architecture can be most useful to the coastal communities on the front lines of climate change. What I learned is that this does not necessarily include a master plan. Here, design is fluid; it needs to be able to change at a moment's notice. Most of all, it needs to be informed by an understanding of the landscape that is at once realistic, cultural and physical. For this project, the format of the guidebook provided the flexibility and tangibility necessary, and allowed the practice of shaping land to be handed over to the communities most directly concerned, while still maintaining the position of the landscape architect. Thus, realizing the power embedded in these landscapes and the agency of the communities that understand them, landscape architecture has the potential to address both the physical and social boundaries already rising around us. LAF

\section{NOTE}

This project was developed during the Masters in Landscape Architecture program at the Harvard Graduate School of Design with Professor. Robert Pietrusko. It was awarded the Thesis Prize from the GSD Landscape Architecture Department. 